\title{
KEAKRABAN PRODUK DAN MINAT BELI FROZEN FOOD: PERAN PENGETAHUAN PRODUK, KEMASAN, DAN LINGKUNGAN SOSIAL
}

\author{
Imam Santoso*), Siti Asmaul Mustaniroh, Dodyk Pranowo \\ Jurusan Teknologi Industri Pertanian, Fakultas Teknologi Pertanian, Universitas Brawijaya, \\ Malang 65145, Indonesia
}

*)E-mail: imam.santoso.ub@gmail.com

\begin{abstract}
Abstrak
Kondisi dinamika masyarakat yang semakin meningkat menyebabkan terjadinya perubahan gaya hidup termasuk pergeseran pola konsumsi pangan dari menggunakan bahan pangan segar beralih sebagian ke produk pangan beku (frozen food). Produk frozen food menjadi salah satu alternatif pilihan rumah tangga dalam memenuhi kebutuhan pangan. Saat ini produk frozen food bervariasi sehingga menuntut konsumen untuk dapat memilih produk olahan pangan terbaik. Penelitian ini bertujuan untuk menganalisis pengaruh pengetahuan produk, kemasan, dan lingkungan sosial terhadap keakraban produk dan pengaruh keakraban produk terhadap minat beli. Penelitian ini dilakukan di Kelurahan Ketawanggede dan Kelurahan Dinoyo, Kecamatan Lowokwaru, Kota Malang. Pengambilan data mengunakan metode judgement sampling dengan instumen kuesioner. Jumlah responden sebanyak 111 konsumen yang telah mengonsumsi frozen food minimal dua kali dalam sebulan dalam tiga bulan terakhir saat pengambilan data dilakukan. Data diolah dengan menggunakan Generalized Structured Component Analysis (GSCA). Hasil penelitian menunjukkan bahwa pengetahuan produk tidak terbukti memberikan pengaruh signifikan terhadap keakraban produk. Kemasan produk dan lingkungan sosial terbukti memberikan pengaruh signifikan terhadap kekaraban produk. Keakraban produk juga terbukti memberikan pengaruh signifikan terhadap minat beli konsumen terhadap produk frozen food.
\end{abstract}

Kata Kunci: frozen food, keakraban produk, kemasan, lingkungan sosial, minat beli

\section{Product Familiarity and Purchase Intention of Frozen Food : The Role of Product Knowledge, Packaging, and Social Environment}

\begin{abstract}
The dynamics condition of society is increasing due to the lifestyle change including shifthing patterns of food consumption from fresh raw food to frozen food products in some of consumers. Nowdays, frozen food products become an alternative options of households to fulfill food needed. Frozen food products is vary so will be influence that the demand of consumers's ability in choosing the best processed food products. This research aimed to analyze the relationship between the product knowledge, packaging, and social environment on familiarity of products and relationship between familiarity of products and purchasing intention among consumers of frozen food. This research was conducted in the Ketawanggede and Dinoyo Village, Lowokwaru Subdistrict, Malang City. Data collection used judgement sampling with the questionnaire as instrument of data collecting. The total of respondents were 111 customers who have cunsomed frozen food at least twice a month in the last-three month when data collecting was conducted. The data analysis used the Generalized Structured Component Analysis (GSCA). The result showed that product knowledge has no significant effect on product familiarity. Packaging and social environment proven have significant effect on product familiarity. Product familiarity also have significant effect on purchasing intention of frozen food.
\end{abstract}

Keywords: frozen food, packaging, product familiarity, purchase intention, social environment

\section{PENDAHULUAN}

Kondisi dinamika masyarakat semakin meningkat seiring dengan terjadinya perubahan lingkungan strategis dalam pengembangan bisnis yang menyebabkan terjadinya perubahan gaya hidup konsumen termasuk didalamnya pergeseran pola konsumsi pangan. Perubahan ini menyebabkan persediaan bahan pangan di tingkat rumah tangga juga mulai bergeser dari semula menggunakan bahan pangan segar beralih sebagian ke produk pangan beku (frozen food). Produk pangan beku (frozen food) merupakan olahan makanan instan beku yang tahan lama dan mudah dalam penyajiannya. Berdasarkan ini, perusahan pengolahan pangan berpacu untuk menghasilkan aneka ragam produk pangan olahan frozen food yang dapat dimanfaatkan 
untuk memenuhi kebutuhan pangan dalam rumah tangga konsumen.

Produk frozen food berbahan dasar daging pada saat ini sangat bervariasi di pasar dan cukup banyak dikonsumsi. Data survei yang dilakukan oleh Kementerian Pertanian (2015) mengungkapkan terjadinya perkembangan yang sangat pesat pada konsumsi olahan daging di tingkat nasional. Rata-rata perkembangan konsumsi olahan daging tiap tahunnya 10,28 persen. Hasil survei lain menyebutkan peningkatan konsumsi sosis rata-rata tumbuh sebesar 4,46 persen per tahun. Produk frozen food seperti nugget, bakso dan sosis merupakan produk daging olahan yang paling banyak dikonsumsi. Meningkatnya permintaan konsumen terhadap frozen food berimbas pada meningkatnya kebutuhan daging ayam dan sapi (Anggraeni, Wijarnako, \& Ningtyas, 2014).

Peningkatan permintaan produk frozen food dan beragamnya pilihan produk menuntut konsumen untuk memilih suatu produk olahan pangan terbaik. Hal ini membuat produsen secara kompetitif berusaha untuk dapat mengenalkan produknya dan meraih pangsa pasar yang lebih luas. Konsumen dalam memilih produk juga mempunyai hak untuk mendapatkan informasi yang jelas, benar, dan jujur terkait barang dan jasa, dan juga hak untuk mengajukan kritik, saran, dan komplain kepada penjual atau produsen jika dirugikan (Simanjuntak, Utami, \& Irni, 2015). Berdasarkan ini, maka produsen harus memberikan informasi yang jelas dan lengkap mengenai produk frozen food sehingga memudahkan konsumen dalam memilih produk sesuai kebutuhan.

Informasi yang diberikan produsen dimanfaatkan konsumen dalam mengenali produk. Semakin sedikitnya informasi yang tersedia dan atau semakin komplek informasi yang ada, akan membuat konsumen semakin tidak pasti dalam memilih produk (Vermeir \& Verbeke, 2006). Konsumen yang mempunyai kemampuan terbatas dalam memproses informasi produk membuat konsumen rentan, yang menyebabkan peluang konsumen membeli atau mengonsumsi produk tanpa pertimbangan yang baik dan matang akan semakin besar. Selain itu, konsumen yang rentan akan mudah ditipu atau mengalami praktik pemasaran yang tidak adil (Simanjuntak, Utami, \& Irni, 2015). Informasi yang disajikan produsen selain sebagai acuan konsumen dalam memilih produk, juga berfungsi sebagai upaya mengenalkan produk.
Hal ini dapat menimbulkan kesan keakraban konsumen terhadap produk yang pada akhirnya akan menentukan minat beli konsumen terhadap produk yang sudah cukup akrab dikenal oleh konsumen.

Keakraban produk didefinisikan sebagai jumlah pengetahuan terkait produk-produk yang dikenal oleh konsumen terutama merek produk dan pengalaman sebagai kemampuan untuk melakukan investigasi terkait dengan produk (Shehryar \& Hunt, 2005). Keakraban produk merupakan sikap yang dapat menyebabkan timbulnya minat beli konsumen. Minat beli mencerminkan perilaku konsumen yang dapat diprediksi di masa mendatang dalam keputusan pembelian (Herrera \& Blanco, 2011). Kajian mengenai keakraban produk terhadap minat beli telah ditelaah sejumlah peneliti, diantaranya yaitu penelitian yang dilakukan oleh Dursun et al. (2011), dengan menggunakan studi pada store brand. Dursun et,al., (2001) mengungkapkan bahwa keakraban produk mempunyai peran penting dalam mendorong minat beli konsumen. Hasil riset tersebut juga menyimpulkan bahwa dibutuhkan tingkat keakraban yang tinggi agar dicapai kinerja store brand yang berhasil. Kaitan keakraban dengan minat beli juga telah diungkapkan oleh hasil riset Laroche, Kim, dan Zhou (1996) yang meneliti minat beli pada sejumlah merek. Hasil pada penelitian tersbeut memperlihatkan bahwa keakraban konsumen terhadap suatu merek memengaruhi kepercayaannya terhadap merek yang bersangkutan, dan pada gilirannya berperan terhadap minat beli.

Keakraban produk dapat diukur dengan seberapa banyak konsumen memahami dan mengira tentang suatu produk. Berdasarkan hasil penelitian Nguyen et al. (2015), terdapat beberapa variabel yang memengaruhi keakraban produk yaitu pengetahuan produk, produk involvement, dan lingkungan sosial. Pengetahuan produk merupakan kumpulan berbagai macam informasi produk meliputi kategori produk, terminologi produk, ciri produk, dan merek secara spesifik (Kusuma \& Untarini, 2014). Pengetahuan dan informasi yang memadai bagi konsumen sangat penting untuk membuat konsumen akrab dengan produk. Verlegh, Steeenkamp, dan Maulenberg (2005) mengungkapkan pengetahuan produk berfungsi sebagai bahan pertimbangan dalam memilih dan mengetahui kualitas dari suatu produk. Jika konsumen mempunyai pengetahuan akan informasi produk, konsumen akan merasa akrab dengan produk yang akan dibeli sehingga konsumen 
percaya pada produk tersebut yang selanjutnya akan terbentuk niat beli (Mayangsari \& Lilik, 2014). Penelitian yang dilakukan oleh Herrera dan Blanco (2011) menyatakan bahwa konsumen yang lebih akrab dengan produk tertentu adalah konsumen yang sudah berpengalaman dan sudah memiliki pengetahuan yang lebih terhadap produk tersebut.

Faktor lain yang memengaruhi keakraban produk yaitu kemasan produk. Kemasan merupakan sarana penting dalam komunikasi produk. Kemasan digunakan sebagai media untuk menyampaikan atribut produk serta citra merek (Becker et al., 2011). Kemasan juga berfungsi sebagai informasi untuk meningkatkan motivasi konsumen dalam membeli produk karena dalam kemasan akan memberikan informasi tentang produk yang memiliki kualitas tinggi. Kemasan sebagai sumber informasi yang disampaikan kepada konsumen membuat konsumen akrab terhadap produk yang dibeli (Verlegh, Steeenkamp, \& Maulenberg, 2005). Heimbach, Johansson, dan MacLachlan (1989) mengungkapkan terdapat korelasi positif signifikan antara keakraban produk dengan penggunaaan nilai-nilai yang diekspresikan dalam suatu label produk. Hasil riset tersbeut mengungkapkan bahwa kepercayaan masyarakat semakin meningkat seiring dengan meningkatnya nilai informasi yang didapatkan dari lingkungan.

Oleh karenanya, lingkungan sosial juga merupakan faktor yang memengaruhi keakraban produk. Lingkungan sosial merupakan faktor yang berhubungan dengan perilaku manusia satu dengan yang lainnya. Lingkungan sosial adalah lingkungan sekitar konsumen yang terdiri dari kelompok rujukan seperti rekan kerja, teman, tetangga, dan keluarga (Jamaliah, Gurmit, \& Rashidah, 2013). Faktor lingkungan sosial dapat berperan menghubungkan minat individu dengan pasar (Kamphuis et al., 2007). Lingkungan sosial seperti keluarga memiliki pengaruh dalam pengambilan keputusan membeli sejumlah besar produk yang ada di pasaran. Banyaknya variasi produk membuat konsumen yang akrab terhadap suatu produk dalam melakukan pembelian akan membandingkan dengan produk lainnya yang terkenal di lingkungan masyarakat. Intensitas suatu produk muncul atau terkenal di kalangan masyarakat baik melalui iklan online maupun offline yang selanjutnya dapat berpengaruh pada keakraban produk dan minat beli kosumen. Hasil penelitian Vermeir dan
Verbeke (2006) menyatakan lingkungan sosial dapat menstimulasi konsumsi dengan cara meningkatkan keterlibatan konsumen dengan produk, mengembangkan norma sosial tertentu, dan terkait dengan ketersediaan produk di pasar yang dapat dijangkau oleh konsumen.

Beberapa penelitian menemukan adanya hubungan antara keakraban produk dengan minat beli. Bui, Kemp, dan Hamilton (2015) dalam penelitiannya mengungkapkan bahwa keakraban produk dapat membantu meningkatkan minat beli walaupun belum dengan tingkat kepercayaa tinggi. Lin \& Lin (2017) juga mengungkapkan terdapat pengaruh positif dan signifikan antara pengetahuan produk terhadap minat beli. Konsumen yang mempunyai pengetahuan tinggi akan mengevaluasi produk berdasarkan kualitasnya karena konsumen percaya dengan pengetahuan produk yang dimiliki. Hal ini akan menyebabkan munculnya kesadaran konsumen terhadap nilai produk dan akibatnya dapat mengembangkan minat beli konsumen. Keakraban juga dipengaruhi oleh pengetahuan produk seperti pada penelitian Sabbe, Verbeke, dan Van Damme (2008) yang menemukan bahwa keakraban konsumen dipengaruhi oleh pengalaman konsumen. Karakteristik sosiodemografis seperti jenis kelamin dan tempat tinggal berpengaruh terhadap keakraban produk, sikap umum konsumen dan keyakinan, serta niat beli. Penelitian Putri (2012) juga mengungkapkan bahwa pengetahuan produk berperan positif dan signifikan terhadap sikap konsumen. Hasil penelitian lain mengenai keakraban produk juga dilakukan oleh Kamphuis et al. (2007) yang menyatakan lingkungan sosial mempunyai hubungan yang positif terhadap keakraban suatu produk. Berdasarkan latar belakang dan telaah penelitian terdahulu, penelitian ini bertujuan untuk menganalisis pengaruh pengetahuan produk, kemasan produk, dan lingkungan sosial terhadap keakraban produk frozen food di tingkat konsumen. Selain itu, penelitian ini juga bertujuan untuk menganalisis pengaruh keakraban produk terhadap minat beli konsumen frozen food.

\section{METODE}

Penelitian ini dirancang menggunakan desain cross sectional. Lokasi penelitian adalah Kelurahan Ketawanggede dan Kelurahan Dinoyo, Kecamatan Lowokwaru, Kota Malang. 
Tabel 1 Variabel dan indikator penelitian

\begin{tabular}{|c|c|c|c|}
\hline Variabel & Definisi Operasional & Indikator & Pustaka \\
\hline \multirow{4}{*}{$\begin{array}{l}\text { Pengetahuan } \\
\text { Produk (X1) }\end{array}$} & \multirow{4}{*}{$\begin{array}{l}\text { Pengetahuan konsumen terhadap } \\
\text { produk yang akan dibeli. }\end{array}$} & Nutrisi $\left(\mathrm{X}_{11}\right)$ & \multirow{4}{*}{$\begin{array}{l}\text { Johnson and Russo } \\
\text { (1984); Nguyen et al. } \\
\text { (2015). }\end{array}$} \\
\hline & & $\operatorname{Rasa}\left(X_{12}\right)$ & \\
\hline & & Daya Tahan $\left(\mathrm{X}_{13}\right)$ & \\
\hline & & Bebas Pengawet $\left(\mathrm{X}_{14}\right)$ & \\
\hline \multirow[t]{2}{*}{ Kemasan (X2) } & \multirow{2}{*}{$\begin{array}{l}\text { Sarana penting yang digunakan } \\
\text { produsen untuk } \\
\text { mengomunikasikan produk kepada } \\
\text { konsumen. }\end{array}$} & Informasi $\left(\mathrm{X}_{21}\right)$ & \multirow{2}{*}{$\begin{array}{l}\text { Rundh (2009); Orth et } \\
\text { al. (2010). }\end{array}$} \\
\hline & & Merek $\left(X_{22}\right)$ & \\
\hline \multirow{2}{*}{$\begin{array}{l}\text { Lingkungan sosial } \\
\text { (X3) }\end{array}$} & \multirow{2}{*}{$\begin{array}{l}\text { Interaksi sosial langsung diantara } \\
\text { kelompok-kelompok masyarakat } \\
\text { yang dapat beperan } \\
\text { menghubungkan minat individu } \\
\text { dengan pasar. }\end{array}$} & Gaya Hidup $\left(\mathrm{X}_{31}\right)$ & \multirow{2}{*}{$\begin{array}{l}\text { Kamphuis et al. } \\
\text { (2006); Nguyen et al. } \\
\text { (2015). }\end{array}$} \\
\hline & & $\begin{array}{l}\text { Teman atau Keluarga } \\
\left(\mathrm{X}_{32}\right) \\
\text { Ketersediaan Produk } \\
\left(\mathrm{X}_{33}\right)\end{array}$ & \\
\hline $\begin{array}{l}\text { Keakraban produk } \\
(\mathrm{Y} 1)\end{array}$ & $\begin{array}{l}\text { Tingkat relasi konsumen dengan } \\
\text { produk sebagai pengaruh } \\
\text { pengalaman bersama dalam } \\
\text { memahami dan mengenal produk. }\end{array}$ & $\begin{array}{l}\text { Frekuensi Pengunaan } \\
\left(\mathrm{Y}_{11}\right) \\
\text { Tingkat konsumsi produk } \\
\left(\mathrm{Y}_{12}\right) \\
\text { Kesukaan terhadap } \\
\text { promosi produk }\left(\mathrm{Y}_{13}\right)\end{array}$ & $\begin{array}{l}\text { Johnson and Russo } \\
\text { (1984); Nguyen et } \\
\text { al.,(2015). }\end{array}$ \\
\hline \multirow[t]{2}{*}{ Minat beli (Y2) } & \multirow{2}{*}{$\begin{array}{l}\text { Kecenderungan konsumen untuk } \\
\text { membeli suatu merek dan } \\
\text { mengambil tindakan yang } \\
\text { berhubungan dengan pembelian. }\end{array}$} & Keinginan $\left(\mathrm{Y}_{21}\right)$ & \multirow[t]{2}{*}{$\begin{array}{l}\text { Sabbe et al. (2008); } \\
\text { Nguyen et al. (2015). }\end{array}$} \\
\hline & & $\begin{array}{l}\text { Kesesuaian harga- } \\
\text { kualitas (Y22) } \\
\text { Kebutuhan (Y23) }\end{array}$ & \\
\hline
\end{tabular}

Kota Malang dipilih sebagai lokasi penelitian karena salah satu kota yang berkembang pertumbuhan industri pariwisatanya dan memengaruhi mobilitas dan kehidupan penduduk asli maupun pendatang. Kehadiran macam perguruan tinggi di Kota Malang juga memengaruhi kehidupan masyarakat. Kedua kelurahan yang dipilih karena wilayah dengan jumlah perguruan tinggi negeri dan swasta terbanyak di Kota Malang. Sebagian besar penduduknya bekerja, baik sebagai pegawai negeri, karyawan swasta, atau berwiraswasta. Pemilihan lokasi tersebut diharapkan dapat menggambarkan dinamika masyarakat yang umumnya sebagai pekerja sehingga ketersediaan frozen food menjadi kebutuhan masyarakat sebagai alternatif produk pangan yang dikonsumsi masyarakat.

Metode pengambilan contoh yang dipilih adalah teknik pengambilan contoh tanpa peluang (nonprobability sampling) yaitu dengan teknik judgement sampling. Judgement sampling adalah teknik pengambilan contoh dengan menggunakan kriteria-kriteria tertentu sesuai kebutuhan penelitian. Penelitian ini dilakukan pada konsumen yang memenuhi kriteria sberusia 17 tahun sampai dengan 55 tahun dan merupakan konsumen frozen food minimal 2 kali dalam 3 bulan terakhir, dengan 111 orang untuk memenuhi syarat analisis.
Data dikumpulkan dengan teknik wawancara secara langsung kepada responden dengan alat bantu kuesioner. Kuesioner yang digunakan dalam penelitian ini merupakan kuesioner skala Likert dengan rentang penilai 1-5. Kuesioner disusun dalam dua bagian, yakni bagian I berisi pertanyaan tentang karakteristik konsumen yang berhubungan dengan pengambilan minat beli frozen food, dan bagian II berisi pertanyaan mengenai faktor-faktor konsumen terhadap keakraban produk dan pengaruhnya terhadap minat beli konsumen.

Pengukuran dan penilaian variabel dilakukan dengan melakukan uji validitas, uji reliabilitas, dan uji linearitas. Uji ini dilakukan dengan menggunakan Statistical Package for the Social Scient (SPSS). Uji validitas digunakan untuk mengukur tingkat kevalidan suatu kuesioner. Instrumen dikatakan valid jika nilai $r$ hitung $>r$ tabel. Uji reliabilitas dilakukan untuk menunjukkan sejauh mana suatu hasil pengukuran relatif konsisten apabila alat ukur tersebut digunakan berulang kali. Instrumen dikatakan reliabel jika nilai Cronbach's alpha > 0,6 . Uji linearitas digunakan untuk melihat keadaan hubungan variabel dependen dengan independen bersifat garis lurus (linear). Linear jika nilai linearity kurang dari 0,5 (Ghozali, 2008). 


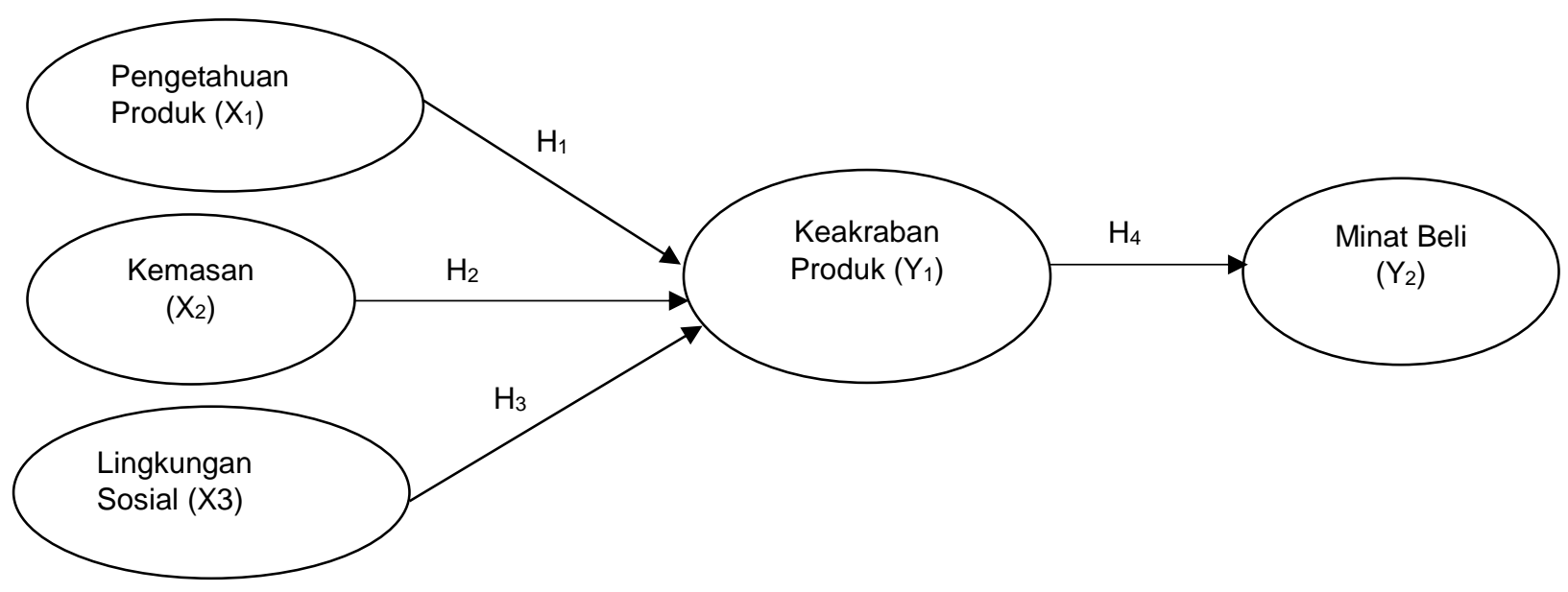

Gambar 1 Model struktural variabel penelitian

Analisis data yang digunakan analisis deskriptif dan inferensial. Analisis deskriptif ditujukan untuk mengidentifikasi karakterstik responden dan kaitannya dengan tingkat konsumsi frozen food. Analisis inferensial menggunakan GSCA (Generalized Structured Component Analysis). Metode ini selain cukup handal, juga tidak mensyaratkan jumlah contoh yang digunakan tidak terlalu besar (Ghozali, 2008). Analisis GSCA digunakan untuk menguji validitas dan reliabilitas konstruk penelitian serta digunakan untuk mengetahui pengaruh dan hubungan antarvariabel yang bersifat formatif dan reflektif.

Pengujian hipotesis dilakukan dengan melihat nilai pada path coefficients (koefisien jalur) pada structural model. Pengujian hipotesis yang dilakukan didasarkan pada Measures of Fit pada model struktural, yakni berdasarkan nilai signifikansi pada estimasi parameternya dilihat dari nilai Critical Ratio. Nilai Critical Ratio yang didapat dibandingkan dengan nilai pada t-tabel (Hwang \& Takane, 2010). Variabel dan indikator yang digunakan pada penelitian ini dapat dilihat pada Tabel 1.

Model struktural variabel penelitian ini dapat dilihat pada Gambar 1 dan konstruksi diagram dapat dilihat pada Gambar 2.

Berdasarkan konstruksi diagram diatas, maka hipotesis untuk penelitian ini yaitu :

Tabel 2 Fit structural model

\begin{tabular}{cr}
\hline Model Fit & Hasil \\
\hline FIT & 0,506 \\
AFIT (Adjusted FIT) & 0,496 \\
NPAR (Number of Free & 34 \\
Parameter Estimated) & 34 \\
\hline
\end{tabular}

$\mathrm{H}_{1}$ : Pengetahuan produk berpengaruh signifikan pada keakraban produk

$\mathrm{H}_{2}$ : Kemasan produk berpengaruh signifikan pada keakraban produk

$\mathrm{H}_{3}$ : Lingkungan sosial berpengaruh signifikan pada keakraban produk

H4: Keakraban produk berpengaruh signifikan pada minat beli konsumen

Hasil uji instrumen menunjukkan bahwa semua indikator telah sesuai dan memenuhi syarat yang telah ditetapkan. Uji validitas semua indikator mempunyai nilai $r$ - hitung $>r$ tabel dengan $(\alpha=0,1 ; d f=110)$. Uji reliabilitas menunjukkan semua variabel pada penelitian memiliki nilai Cronbach's alpha di atas 0,6, sehingga semua indikator dan variabel valid dan reliabel. Hasil uji linieritas nilai sig semua variabel $X$ terhadap $Y_{1}$ telah linier dan antara $Y_{1}$ dan $Y_{2}$. Uji instrumen lain dengan Generalized Structured Component Analysis (GSCA) yaitu evaluasi model struktural yang dapat dilihat pada Tabel 2.

Tabel 2 menunjukkan nilai FIT digunakan untuk menunjukkan varian dari total semua variabel yang dapat dijelaskan oleh model. Nilai FIT berkisar dari 0 sampai 1 dengan standar nilainya disarankan lebih besar dari 0,5 . Berdasarkan hasil analisis model yang terbentuk dapat dilihat nilai FIT yaitu 0,506 yang nilai tersebut lebih dari 0,5 sehingga nilai FIT sudah sesuai. Nilai FIT menjelaskan semua variabel yang ada sebesar 0,506 yang artinya variabel pengetahuan produk, kemasan produk, lingkungan sosial, keakraban produk, dan minat beli dapat dijelaskan oleh model sebesar 50,6 persen dan sisanya 49,6 persen dapat dijelaskan oleh variabel lain. AFIT (Adjusted FIT) merupakan nilai FIT yang sudah terkoreksi. Standar nilai AFIT yang direkomendasikan yaitu lebih besar dari 0,5. 


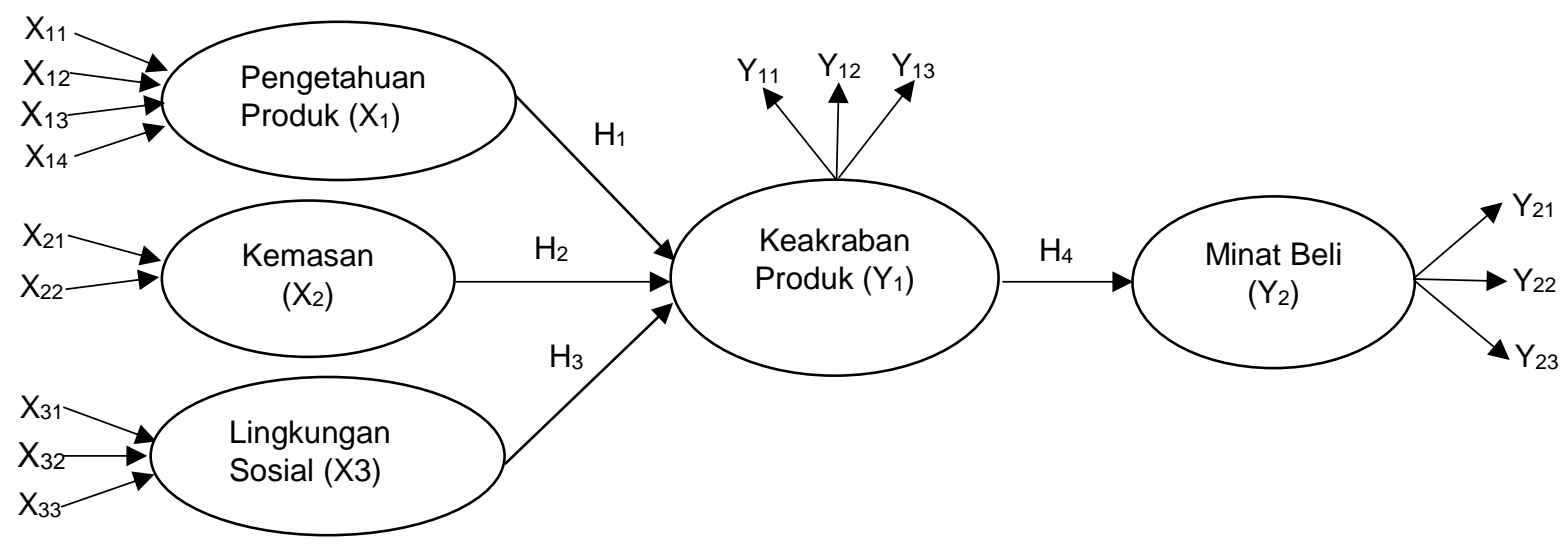

Gambar 2. Konstruksi

Nilai AFIT yang dihasilkan 0,496 yang nilainya kurang dari 0,5 sehingga kurang sesuai. NPAR (Number of Free Parameter Estimated) menunjukkan banyaknya parameter bebas yang digunakan dalam perhitungan yaitu sebanyak 34 .

\section{HASIL}

\section{Karakteristik Responden}

Responden yang dipilih wanita dikarenakan dalam keseharian atau dalam rumah tangga wanita sebagai decision maker yang menentukan pembelian dari suatu produk, terutama produk untuk kebutuhan konsumsi. Karateristik responden secara detail disajikan dalam Tabel 3.

Berdasarkan karakteristik usia, sebagian besar reponden berusia $26-55$ tahun $(63,0 \%)$ dan 1725 tahun $(37,0 \%)$ yang menunjukkan bahwa sebagian besar berada dalam usia produktif.

Tabel 3. Karakteristik responden

\begin{tabular}{llcc}
\hline Karakeristik & Gambaran responden & $\mathrm{N}$ & $\%$ \\
\hline Usia (tahun) & $17-25$ & 48 & 43,2 \\
& $26-55$ & 63 & 56,8 \\
\hline Pendidikan & SMP & 4 & 3,6 \\
& SMA & 34 & 30,6 \\
& Perguruan tinggi & 73 & 65,8 \\
\hline Pekerjaan & Mahasiswa & 14 & 12,6 \\
& Tidak Bekerja & 7 & 8,1 \\
& lbu rumah tangga & 27 & 24,0 \\
& Pegawai negeri & 21 & 19,0 \\
& Pegawai swasta & 33 & 30,0 \\
& Wiraswasta & 9 & 6,3 \\
\hline Penghasilan & Rpp2.000.000,00 & 48 & 43,2 \\
& Rp2.000.000,00- & 19 & 17,1 \\
& Rp3.000.000,00 & & \\
& Rp3.001.000- & 17 & 15,3 \\
& Rp4.000.000,00 & & \\
& Rp4.001.000- & 12 & 10,8 \\
& Rp5.000.000,00 & 15 & 13,6 \\
\hline & >Rp5.000.000 & &
\end{tabular}

Tingkat pendidikan memperlihatkan bahwa konsumen frozen food memiliki tingkat pendidikan yang baik. Hal ini ditunjukkan tingkat pendidikan responden hampir dua pertiga lulusan perguruan tinggi $(65,8 \%)$, SMA atau sederajat $(30,6 \%)$, sedangkan untuk tingkat pendidikan SMP sederajat hanya sebanyak (3,6\%). Hasil penelitian juga menunjukkan bahwa sebagian besar responden memiliki pendidikan tinggi sehingga diharapkan memiliki pengetahuan produk yang baik. Sementara pekerjaan konsumen adalah $(30,0 \%)$ pegawai swasta, ibu rumah tangga $(24,0 \%)$, pegawai negeri $(19,0 \%)$, wiraswasta $(6,3 \%)$ mahasiswa $(12,6 \%)$, serta tidak bekerja $(6,3 \%)$.

Responden berpenghasilan kurang dari Rp2000.000,00 sebanyak 48 orang (43,2\%). Responden dengan penghasilan Rp2.000.000,00-Rp3.000.000,00 sebanyak 19 orang $(17,1 \%)$, penghasilan Rp3.001.000,00Rp4.000.000,00 sebanyak 17 orang (15,3\%). Responden dengan penghasilan Rp4.010.000,00-Rp5.000.000,00 sebanyak 12 orang $(10,8 \%)$ dan penghasilan sebesar lebih dari Rp5.000.000,00 adalah sebanyak 15 orang $(13,6 \%)$.

\section{Pengaruh pengetahuan produk, kemasan produk, dan lingkungan sosial terhadap keakraban produk dan minat beli}

Hasil analisis hipotesis dapat dilihat pada Gambar 3. Penelitian ini menggunakan GSCA, pengujian hipotesis dilakukan dengan menilai dan membandingkan nilai Critical Ratio (CR) dengan t-tabel. Sesuai dengan jumlah contoh penelitian dan uji 2 arah, maka keputusan untuk menolak dan menerima hipotesis adalah jika nilai $\mathrm{CR}>1,96$. Artinya, jika nilai $\mathrm{CR}$ kurang dari 1,96 maka hipotesis penelitian tidak diterima atau ditolak, sehingga hipotesis nol $\left(\mathrm{H}_{0}\right)$ diterima. 


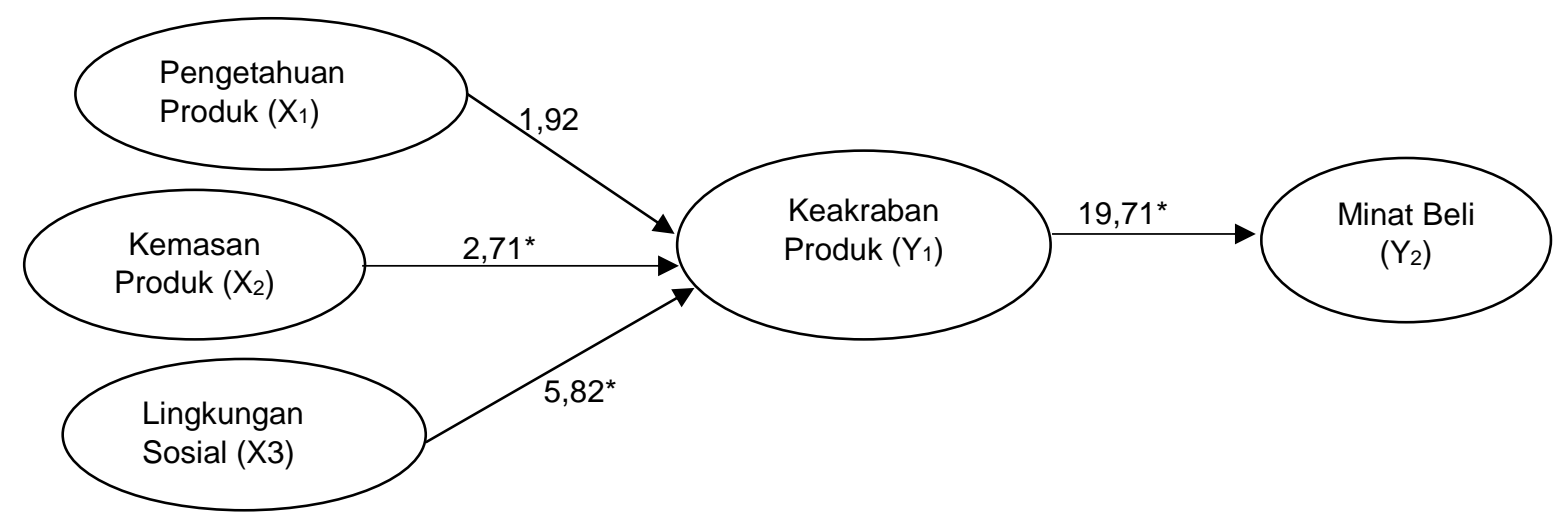

*Signifikan pada level 0,05

Gambar 3. Konversi nilai koefisien jalur model struktural

Berdasarkan hasil analisis menunjukkan bahwa jalur hubungan antara variabel pengetahuan produk terhadap keakraban produk tidak berpengaruh signifikan. Hal ini dapat diketahui dari nilai jalur pengetahuan produk terhadap keakraban produk adalah 0,159 dan memiliki nilai CR 1,92 yang nilainya lebih kecil dari 1,96 sehingga artinya nilai jalur positif namun tidak signifikan pada tingkat signifikansi 0,05 . Artinya dapat disimpulkan bahwa $\mathrm{H}_{0}$ diterima dan $\mathrm{H}_{1}$ ditolak.

Jalur hubungan variabel kemasan produk terhadap keakraban produk menunjukkan nilai jalur dari kemasan terhadap keakraban adalah 0,268 dan memiliki nilai CR sebesar 2,71 yang nilainya lebih besar dari 1,96. Hal ini berarti bahwa terdapat pengaruh positif dan signifikan pada tingkat signifikansi 0,05 . Artinya bahwa $\mathrm{H}_{0}$ ditolak dan $\mathrm{H}_{1}$ diterima. Hal ini berarti kemasan produk berpengaruh positif dan signifikan terhadap keakraban produk.

Jalur hubungan lingkungan sosial terhadap keakraban produk menunjukkan nilai koefisien jalur 0,483 dan memiliki nilai CR 5,82 yang nilainya lebih besar dari 1,96. Hal ini berarti terdapat pengaruh positif dan signifikan pada variabel lingkungan sosial terhadap keakraban produk pada tingkat signifikansi 0,05 . Artinya bahwa $\mathrm{H}_{0}$ ditolak dan $\mathrm{H}_{1}$ diterima sehingga dapat disebutkan bahwa lingkungan sosial berpengaruh terhadap keakraban produk.

Hasil uji statistik juga menunjukkan hubungan kekaraban produk terhadap minat beli konsumen. Pada tingkat signifikansi 0,05 menunjukkan bahwa nilai jalur dari keakraban produk adalah 0,738 dan dengan nilai $\mathrm{CR}$ sebesar 19,71 yang nilainya lebih dari 1,96. Nilai hasil analisis ini bersifat positif dan signifikan. Artinya bahwa $\mathrm{H}_{0}$ ditolak dan $\mathrm{H}_{1}$ diterima. Hal ini berarti bahwa keakraban produk memberikan pengaruh positif dan siginifkan terhadap minat beli konsumen.

Nilai estimate pada path coefficients dapat digunakan untuk menentukan model matematis yang terbentuk dari suatu diagram penelitian. Pada penelitian ini persamaaan yang terbentuk dari variabel $X_{1}$ (pengetahuan produk), $X_{2}$ (kemasan produk), $X_{3}$ (lingkungan sosial), $Y_{1}$ (keakraban produk), dan $Y_{2}$ (minat beli) adalah: $\mathrm{Y}_{2}=0,159 \mathrm{X}_{1}+0,268 \mathrm{X}_{2}+0,483 \mathrm{X}_{3}+0,738 \mathrm{Y}_{1}$. Koefisien determinasi total yang ditunjukkan oleh nilai FIT dari model sebesar 50,5 persen.

\section{PEMBAHASAN}

Perkembangan industri makanan olahan saat ini semakin meningkat diakibatkan daya beli konsumen yang meningkat dan perubahan pola hidup masyarakat Indonesia yang beralih dari produk makanan segar ke produk siap saji seperti frozen food. Frozen food merupakan olahan makanan instan beku yang tahan lama dan mudah dalam penyajiannya. Saat ini produk olahan daging ayam maupun sapi seperti frozen food menjadi pasar yang menjanjikan di Indonesia. Produk frozen food dapat dengan mudah dijumpai oleh konsumen baik di tingkat pasar tradisional dan di supermarket. Perubahan gaya hidup pada masyarakat Kota Malang berpengaruh pada pola konsumsi makanan masyarakat. Seperti halnya penduduk di kota besar lainnya, penduduk Kota Malang cenderung tertarik pada produk makanan instan yang tahan lama dan mudah dalam penyajiannya. Tingkat konsumsi makanan olahan yang lebih digemari oleh masyarakat saat ini adalah sosis, bakso dan nugget. Produk frozen food bakso dan sosis merupakan produk daging olahan yang paling banyak dikonsumsi.

Tingkat permintaan konsumsi produk frozen 
food dipengaruhi oleh beberapa faktor, yaitu pengetahuan konsumen tentang produk frozen food, kemasan pada produk, dan lingkungan sosial dari konsumen. Konsumen cenderung mengonsumsi produk frozen food dikarenakan kesibukan bekerja dan menjalankan aktivitas di luar rumah namun ingin tetap menyajikan makanan sendiri. Selain itu, konsumen frozen food dalam melakukan minat beli produk dan mengonsumsi produk juga dipengaruhi oleh tingkat keakraban atau pengenalan produk dengan konsumen. Konsumen yang mengenal produk dengan baik maka akan membeli produk tersebut. Pengenalan dan keakraban produk dapat diciptakan dengan melakukan promosi produk baik secara online maupun secara offline pada konsumen.

Hasil penelitian menunjukkan pengetahuan produk tidak berpengaruh terhadap keakraban produk. Hal ini berarti belum terdapat bukti yang memadai bahwa pengetahuan produk berpengaruh terhadap keakraban produk. Hasil ini diduga konsumen frozen food merupakan masyarakat yang hanya memfokuskan pada ketersediaan produk makanan cepat saji dan tahan lama. Adapun ditemukan sebagain besar konsumen belum sepenuhnya memperhatikan informasi berbagai hal terkait frozen food. Hal ini sesuai dengan penelitian yang dilakukan oleh Saleh dan Nella (2011) yang mengungkapkan bahwa pengetahuan konsumen mengenai produk frozen food seperti sosis hanya sebesar empat persen. Konsumen mengonsumsi frozen food hanya dikarenakan kebutuhan untuk konsumsi sehingga konsumen tidak memerhatikan aspek lain dalam produk sebagai pertimbangan. Padahal semakin banyak informasi dan pengetahuan yang diperoleh akan menjadi dasar dan memengaruhi keakraban produk. Pengetahuan produk diartikan sebagai jumlah informasi yang disimpan dalam ingatan konsumen mengenai berbagai atribut produk. Pengetahuan akan muncul ketika seseorang menggunakan indera dan akalnya untuk mengenali produk yang dipasarkan (Saleh \& Nella, 2011).

Saat ini berbagai jenis merek yang ditawarkan untuk produk frozen food sangat beragam, sehingga konsumen tidak mampu membedakan merek yang satu dengan yang lainnya. Konsumen produk frozen food cenderung membeli produk yang sering muncul di iklan baik online maupun offline. Konsumen enggan untuk membaca atau mencari produk yang tidak terkenal luas di pasaran. Padahal kenyataannya belum tentu produk yang tidak akrab di pasar tidak bermutu. Pengetahuan konsumen yang rendah terhadap suatu produk mengakibatkan konsumen mengandalkan atribut harga dan merek yang akrab di pasaran untuk membeli suatu produk. Vermeir \& Verbeka (2006) juga menjelaskan bahwa konsumen yang mempunyai pengetahuan kurang terhadap suatu produk akan menyebabkan konsumen semakin tidak pasti dalam memilih suatu produk. Menurut Clarkson, Janiszewski, dan Cinelli (2013), konsumen pemula biasanya tidak memiliki pengetahuan yang memadai tentang suatu produk yang ingin dikonsumsinya. Beberapa kasus konsumen ingin mencoba untuk mengonsumsi terlebih dahulu suatu produk sehingga dapat terbangun suatu pengetahuan terhadap produk baru. Namun demikian, secara umum konsumen lebih cenderung untuk mencari informasi yang memadai sebelum membuat minat beli. Hasil penelitian Campbell dan Keller (2003) mengungkapkan bahwa tidak mudah membangun pengetahuan mengenai suatu merek produk dikarenakan hal tersebut membutuhkan komunikasi yang efektif. Hasil penelitian ini juga menguatkan argumentasi dan temuan hasil penelitian Berthon, Pitt, dan Campbell (2009) yang menemukan bahwa ketidakefektifan komunikasi dapat diakibatkan oleh ketidaksesuaian tingkat pengetahuan yang dimiliki perancang pesan dengan konsumen.

Hasil penelitian ini juga mengungkapan bahwa kemasan pada produk berpengaruh positif dan signifikan pada keakraban produk. Hal ini menunjukkan bahwa kesan pertama yang dilihat oleh konsumen dalam melakukan pembelian atau memilih suatu produk adalah berdasarkan kemasan dari produk. Kemasan pada produk merupakan bagian integral produk dan menggambarkan citra merek yang dapat digunakan sebagai media informasi antar konsumen dengan produk (Santoso \& Fitriyani, 2016). Kemasan yang digunakan pada frozen food berbeda dengan kemasan yang digunakan pada produk makanan cepat saji lainnya. Hal ini karena kemasan frozen food harus dapat melindungi produk sehingga dapat bertahan di ruangan yang dingin serta mencapai titik beku. Secara keseluruhan kemasan produk frozen food menggunakan plastik yang tidak dapat dimasuki atau ditembus udara. Kemasan pada frozen food adalah jenis plastik nylon yang terbuat dari bahan polyethylene terephthalate (PET) yang telah dilapisi dengan Low density polyethylene (LDPE).

Menurut Rundh (2009), kemasan tidak saja 
melindungi bahan pangan namun juga berperan memberikan banyak informasi sehingga dapat membantu peran tenaga pemasaran. Poduk frozen food yang saat ini semakin banyak dan bervariasi membuat konsumen dapat memilih dan membeli produk frozen food sesuai kebutuhannya. Berbagai macam variasi ini membuat kemasan produk yang berisi kelengkapan informasi berpengaruh terhadap keakraban produk. Semakin lengkap informasi yang terdapat pada kemasan produk frozen food maka konsumen akan semakin akrab dengan produk tersebut. Konsumen dapat mengenal dan membedakan berbagai produk frozen food dengan berbagai kelebihan dan kelemahannya masing-masing. Desain kemasan produk frozen food yang menarik juga akan memberikan daya tarik tersendiri bagi konsumen. Bentuk kemasan yang unik dan berbeda dengan produk olahan daging lainnya akan memberikan kesan keakraban tersendiri pada konsumen.

Hasil penelitian ini juga sejalan dengan penelitian yang dilakukan oleh Ovrum et al. (2012), yang menyatakan bahwa kemasan secara positif berpengaruh pada preferensi konsumen. Konsumen bersedia membayar lebih terhadap suatu produk yang memiliki kemasan yang menarik. Orth, Campana, dan Malkewitz (2010) mengatakan bahwa desain kemasan merupakan bagian integral yang mengambarkan citra merek pada suatu produk yang dirancang untuk menyampaikan informasi yang ada pada produk. Label atau kemasan pada produk frozen food dijadikan perusahaan sebagai strategi untuk memasarkan produknya dan untuk membedakan produknya dengan produk lain sehingga dapat menarik minat konsumen dalam membeli produk frozen food.

Berdasarkan hasil penelitian ini, lingkungan sosial berpengaruh positif pada keakraban produk. Hal ini menunjukkan bahwa teman, keluarga dan rekan kerja memengaruhi seseorang dalam mengenal, memilih, dan memutuskan untuk mengonsumsi produk frozen food. Hal ini diperkuat oleh berbagai proses interpersonal yang berpengaruh dominan dalam keluarga dan tema lingkungan kerja. Kondisi ini secara nyata memengaruhi perilaku seseorang dalam memilih dan menentukan jenis-jenis makanan yang disediakan untuk sendiri maupun keluarga. Hasil penelitian ini sesuai beberapa penelitian terdahulu seperti Zhu dan Chang, (2015) dan juga Vabo dan Hansen (2014) yang juga menemukan bahwa lingkungan sosial berupa keluarga, teman dan rekan kerja berpengaruh terhadap keputusan pembelian produk pangan.

Sebagian besar responden konsumen frozen food setiap harinya akan melakukan interaksi kurang lebih 10 orang dengan tetangga, teman, keluarga, maupun rekan kerja. Responden pada penelitian ini adalah wanita, yang umumnya akan saling bercerita dan berbicara tentang suatu produk, baik produk pangan maupun nonpangan. Apabila masingmasing dari responden saling bercerita dan berinteraksi dengan yang lainnya maka akan saling bertukar informasi terkait produk frozen food yang dikonsumsi. Konsumen akan saling memberikan informasi dan rekomendasi terkait produk frozen food yang baik dan aman untuk dikonsumsi. Pola komunikasi dan interaksi ini akan membentuk suatu jaringan interaksi sosial yang luas dan akan berimbas pada keakraban konsumen terhadap suatu produk. Menurut Kamphuis et al. (2006), lingkungan sosial merupakan faktor yang berhubungan dengan perilaku manusia satu dengan yang lainnya.

Hasil penelitian ini sejalan dengan penelitian yang dilakukan oleh Kamphuis et al. (2007) yang menyatakan bahwa terdapat pengaruh positif faktor lingkungan sosial terhadap keakraban suatu produk. Perilaku konsumen berpengaruh terhadap persepsi konsumen ke suatu produk. Kondisi pasar juga berdampak terhadap jumlah konsumen. Jika konsumen tertarik dengan orang-orang yang ada di pasar, konsumen akan merasa akrab dengan produk meskipun tidak membelinya. Hal ini membuat semakin lama konsumen dalam melakukan pembelian suatu produk.

Hasil penelitian menunjukkan keakraban produk berpengaruh positif terhadap minat beli konsumen. Konsumen frozen food yang familiar terhadap merek produk akan memutuskan untuk membeli produk tersebut tanpa ragu-ragu. Bentuk dari keakraban terhadap frozen food diperoleh oleh konsumen melalui iklan maupun rekomendasi dari teman dan keluarga. Semakin sering jenis suatu merek produk frozen food muncul di iklan atau di majalah maka konsumen akan semakin mengenal produk tersebut sehingga menimbulkan keinginan untuk melakukan pembelian.

Harga yang terjangkau dan sesuai dengan isi produk frozen food yang ditawarkan juga berpengaruh pada minat beli konsumen. Konsumen cenderung menginginkan produk 
yang lebih murah dengan kualitas yang baik. Selain dari sisi harga produk, familiarity produk frozen food dapat dilihat dari kemudahan dalam memperoleh frozen food. Saat ini frozen food telah dipasarkan di berbagai tempat baik di pasar tradisional maupun pasar modern, konsumen dapat dengan mudah untuk memperoleh frozen food. Tingkat konsumsi produk frozen food juga semakin tinggi, terbukti dengan meningkatnya konsumsi daging rata-rata yaitu $2,08 \mathrm{~kg} / \mathrm{kapita} / \mathrm{tahun}$ (Kementerian Pertanian, 2015). Semakin sering konsumen melihat produk dan melihat orang lain mengonsumsi frozen food maka konsumen akan semakin akrab dan akan turut serta membeli produk tersebut. Menurut Kuester (2012), terdapat empat faktor yang memengaruhi konsumen untuk membeli suatu produk yaitu kualitas, harga, merek dan ketersediaan produk di pasaran. Ketika konsumen lebih akrab dengan kategori produk tertentu, konsumen akan cenderung mengandalkan nama merek dalam produk ketika berminat untuk mengonsumsi suatu produk.

Hasil penelitian ini juga sejalan dengan penelitian Bui, Kemp, dan Hamilton (2015) yang menemukan bahwa keakraban produk berpengaruh positif dan berperan meningkatkan minat beli. Loginova (2010) juga menjelaskan bahwa konsumen benar-benar mempertimbangkan merek sebagai syarat penting bagi nama produk dan membuat keputusan pembelian. Konsumen yang akrab dengan produk dapat dengan mudah mengenali kebutuhannya sesuai karakteristik yang tepat dari suatu merek. Menurut Kuester (2012), keakraban produk memiliki peranan penting dalam pemilihan keputusan.

\section{SIMPULAN DAN SARAN}

Hasil pengujian hipotesis menunjukkan bahwa pengetahuan produk belum terdapat bukti yang memadai memberikan pengaruh signifikan terhadap keakraban produk. Hal ini diduga karena sebagian konsumen umumnya telah mengetahui dan mengenal informasi produk frozen food dari berbagai media sehingga pengetahuan tentang produk frozen food relatif lengkap. Kemasan berpengaruh secara signifikan terhadap keakraban produk. Hal ini karena kemasan berperan strategis baik dari aspek fungsional maupun sebagai media promosi. Kesan pertama yang dilihat oleh konsumen dalam melakukan pembelian adalah kemasan sehingga jika kemasan menarik maka konsumen akan lebuh mudah untuk mengenali produk lebih lanjut.
Lingkungan sosial berpengaruh signifikan pada keakraban produk. Hal ini disebabkan teman dan keluarga memberikan pengaruh tersendiri dalam konsumen untuk membeli suatu produk. Sebagian responden membeli frozen food karena rekomendasi dari keluarga dan teman serta iklan yang ada di media sosial baik online maupun offline. Keakraban produk berpengaruh secara signifikan pada minat beli. Hal ini dikarenakan konsumen membeli produk apabila produk tersebut telah dikenal dengan baik dan mudah diperoleh.

Berdasarkan hasil penelitian di atas maka diharapkan konsumen dapat mengetahui berbagai informasi produk sehingga mempunyai pengetahuan terhadap banyak produk frozen food untuk dapat menelaah keunggulan merek produk satu dengan lainnya. Perusahaan juga diharapkan memberikan informasi yang spesifik mengenai produknya sehingga konsumen mudah mengenali dan membedakan produk.

\section{DAFTAR PUSTAKA}

Anggraeni, D.A., Widjanarko, S.B. \& Ningtyas, D.W. (2014). Proporsi tepung porang (amorphophallus muelleri blume) tepung maizena terhadap karakteristik sosis ayam. Jurnal Pangan dan Agroindustri, 2(3): 214-223.

Becker, L., van Rompay, T.J. L., Schifferstein, H.N.J., \& Galetzka, M., (2011). Tough package, strong taste: the influence of packaging design on taste impressions and product evaluations. Food Quality \& Preference, 1(22): 17-23.

Berthon, P., Pitt, L.F., \& Campbell, C. (2009). Does brand meaning exist in similarity or singularity? Journal of Business Research, 62(3): 356-361.

Bui, M., Kemp, E. \& Hamilton, M. (2015). The power of promoting healthy brands: familiarity in healthy product decision making. Journal of Promotion Management. 21(6):739-759.DOI: 10.1080/10496491.2015.1088920.

Campbell, M.C. \& Keller, K.L. (2003). Brand familiarity and advertising repetition effects. Journal of Consumer Research, 30(2): 292-304.

Clarkson, J., C. Janiszewski, \& M. D. Cinelli. (2013). The desire for consumption knowledge. Journal of Consumer Research, 39(6):1313-1329.

Dursun, I. Kabadayi, E.T., Alan, A.K., Sezen, 
B. (2011). Store brand purchase intention: effects of risk, quality, familiarity and store brand shelf space. Journal of Global Strategic Management, 5(2):

$113-$

123.DOI:10.20460/JGSM.2011515802.

Ghozali, I. (2008). Generalized Structured Component Analysis (GSCA) Model Persamaan Struktural Berbasis Komponen. Semarang. Badan Penerbit Universitas Diponegoro.

Heimbach, A.E., Johansson, J.K. \& MacLachlan, D.L. (1989). Product familiarity, information processing, and country-of-origin cues in NA. Advances in Consumer Research. 16: 460-467.

Herrera, C.F. \& Blanco, C.F. (2011). Consequences of consumer trust in pdo food products the role of familiarity. Journal of Product \& Brand Management. 20(4):282-296.

Hwang, H., \& Takane,Y. (2004). Generalized structured component analysis. Psychometrica. 69 (1): 81-99.

Jamaliah, M.D., Gurmit, K. B., \& Rashidah, A.R. 2013. Purchase intention of environment-friendly automobile. Journal Procedia - Social and Behavioral Sciences. 8(5): 400 - 410.DOI: 10.1016/j.sbspro.2013.08.369.

Johnson, E.J. \& Russo, J.E., (1984). Product Familiarity and Learning New Information. Journal of Consumer Research, 11 (1) : 542-550. https://doi.org/10.1086/208990.

Kamphuis, C., Giskes, K., de Bruijn, G. J., Wendel-Vos, W., Brug, J., \& Van Lenthe, F. J. (2006). Environmental determinants of fruit and vegetable consumption among adults: a systematic review. British Journal of Nutrition. 96(4): 620635.

Kamphuis, C.B., van Lenthe, F.J., Giskes, K., Brug, J., Mackenbach, J.P. (2007). Perceived environmental determinants of physical activity and fruit and vegetable consumption among high and low socioeconomic groups in the Netherlands. Health \& Place. 13(2): 493503.

DOI:10.1016/j.healthplace.2006.05.008.

Kementerian Pertanian. (2015). Outlook Komoditas Pertanian Sub Sektor Peternakan Daging Sapi. ISSN:19071507.
Kuester, S. (2012). MKT I: Strategic Marketing \& Marketing in Specific Industry Contexts. University of Mannheim.

Kusuma, I.D. \& Untarini, N. (2014). Pengaruh pengetahuan produk terhadap niat beli dengan sikap sebagai variabel intervening. Jurnal IImu Manajemen 2(4): 1573-1583.

Laroche, M., Kim, C., \& Zhou, L. (1996). Brand familiarity and confidence as determinants of purchase intention: an empirical test in a multiple brand context. Journal of Business Research, 37(2) :115-1920.

Lin, N. \& Lin, B., (2007). The effect of brand image and product knowledge on purchase intention moderated by price discount. Journal of International Management Studies, 2(2) :121-132.

Loginova, O. (2010). Brand familiarity and product knowledge in custmization. International Journal of Economic Theory. (6):297-309.DOI: 10.1111/j.1742-7363.2010.00136.x.

Mayangsari, L., \& Lilik, R. (2014). Pengaruh dukungan endorser dan brand familiarity terhadap perception of purchase risk dan dampaknya pada niat beli produk brand extention. Jurnal Manajemen Teori dan Terapan. 7(2):134-147.

Nguyen, P.V., Dang, N.H.X., Do, Q. L. N. \& Mai, K.T. (2015). The impacts of consumers' familiarity on their behavioral intentions towards frozen pangasius products: a study in Ho Chi Minh City, Vietnam. Review of European Studies, 7(7): 97-106.

Orth, U. R., Campana, D., \& Malkewitz, K. (2010). Formation of consumer price expectation based on package design: attractive and quality routes. Journal of Marketing Theory and Practice, 18(1):340.

Ovrum, A., Alfnes, F., Almli, V. L., \& Rickertsen, K. (2012). Health information and diet choices: results from a cheese experiment. Food Policy. 37(5): 520-529

Putri, P.K.D. (2012). Pengaruh tingkat pendidikan, pengetahuan, sikap, dan terpaan iklan layanan masyarakat KB versi Shireen Sungkar dan Teuku Wisnu di TV terhadap perilaku KB pada wanita atau pria dalam usia subur. Jurnal Interaksi. 1(1): 46-56. 
Rundh, B. (2009). Packaging design: creating competitive advantage with product packaging. British Food Journal. 111(9): 988-1002.

Sabbe, S., Verbeke, W., Van Damme,P. (2008). Familiarity and purchasing intention of belgian consumers for fresh and processed tropical fruit products. British Food Journal, 110(8):805 - 818.DOI:10.1108/ 00070700810893331

Saleh, I.M. \& Nella, R.M. (2011). Hubungan antara pengetahuan merek sozzis dengan volume pembelian produk sosis merek Sozzis Pada PT.Carrefour Cabang MTC Karebosi, Makassar. Jurnal Agribisnis. 10(3): 58-68.

Santoso, I \& Fitriyani, R (2016). Green packaging, green product, green advertising, persepsi, dan minat beli konsumen. Jurnal IImu Keluarga dan Konsumen. $\quad 9(2)$ : 147158.DOI:10.24156/jikk.2016.9.2.147

Shehryar, D. \& Hunt, D.M. 2005. Buyer behavior and procedural fairness in pricing: exploring the moderating role of product familiarity. Journal of Product \& Brand Management. 14(4): 271-276. DOI: $10.1108 / 10610420510609294$

Simanjuntak, M., Utami, F.S \& Irni, R.J. (2015).
Kerentanan konsumen dan perilaku pembelian produk makanan kemasan. Jurnal Ilmu Keluarga \& Konsumen, 8(3):193-203.

DOI:10.24156/jikk.2015.8.3.193

Vabo, M., \& Hansen, H., (2014). The relationship between food preferences and food choice: a theoretical discussion. International Journal of Business and Social Science, 5(7): 145-157.

Verlegh, P. W., Steenkamp, J. B. E., \& Meulenberg, M. T. (2005). Country of origin effects in consumer processing of advertising claims. International Journal of Research in Marketing, 22(2):127139.

DOI:10.1016/j.jijresmar.2004.05.003.

Vermeir, I. \& Verbeke, W. (2006). Sustainable Food Consumption: Exploring the Consumer "Attitude - Behavioral Intention" gap. Journal of Agricultural and Environmental Ethics. 19:169-19.4 DOI:10.1007/s10806-005-5485-3.

Zhu, D.H. \& Chang, Y.P., (2015). Effects of interactions and product information on initial purchase intention in product placement in social games: the moderating role of product familiarity. Journal of Electronic Commerce Research, 16(1): 22-233. 